\title{
Anodic Dissolution of Spheroidal Graphite Cast Iron with Different Pearlite Areas in Sulfuric Acid Solutions
}

\author{
Yoshikazu Miyata, ${ }^{1}$ Yuki Kuwahara, ${ }^{1,2}$ Shukuji Asakura, ${ }^{1}$ Tadashi Shinohara, ${ }^{1,3}$ \\ Takao Yakou, ${ }^{1}$ and Keiichi Shiimoto ${ }^{2}$ \\ ${ }^{1}$ Graduate School of Engineering, Yokohama National University, 79-5 Tokiwadai, Hodogaya-ku, Yokohama 240-8501, Japan \\ ${ }^{2}$ Hinode Suido, Ltd., 5-8-18 Katakasu, Hakata-ku, Fukuoka 812-8636, Japan \\ ${ }^{3}$ National Institute for Materials Science, 1-2-1 Sengen, Tsukuba, Ibaraki 305-0047, Japan \\ Correspondence should be addressed to Yoshikazu Miyata; y.miyata@ynu.ac.jp
}

Received 10 July 2013; Revised 3 September 2013; Accepted 16 September 2013

Academic Editor: W. Ke

Copyright (c) 2013 Yoshikazu Miyata et al. This is an open access article distributed under the Creative Commons Attribution License, which permits unrestricted use, distribution, and reproduction in any medium, provided the original work is properly cited.

\begin{abstract}
The rate equation of anodic dissolution reaction of spheroidal graphite cast iron in sulfuric acid solutions at $298 \mathrm{~K}$ has been studied. The cast irons have different areas of pearlite. The anodic Tafel slope of $0.043 \mathrm{~V}$ decade ${ }^{-1}$ and the reaction order with respect to the hydroxyl ion activity of 1 are obtained by the linear potential sweep technique. The anodic current density does not depend on the area of pearlite. There is no difference in the anodic dissolution reaction mechanisms between pure iron and spheroidal graphite cast iron. The anodic current density of the cast iron is higher than that of the pure iron.
\end{abstract}

\section{Introduction}

Cast iron is widely used for pipes in neutral environments such as water and soil. A lot of experimental studies of cast iron for practical use were conducted [1-8]. A form of corrosion unique to cast irons is a selective leaching attack commonly referred to as graphitic corrosion [9, page 89]. A graphite network forms a corrosion-resistant phase called a graphitic layer. Therefore, the corrosion resistance of cast iron is said to be higher than that of steel. That is not necessarily the case.

Laque reported that the corrosion rate of cast irons is lower than that of a steel in the atmosphere above the sea [2]. However, Paris and Bruniere [1] and Horikawa et al. [10] found that the corrosion rate of cast irons is nearly equal to that of steel in water and in atmosphere. Furthermore, a book said that graphitic corrosion does not occur in spheroidal graphite cast irons, because the graphite network does not exist [9, page 89], while another author reported that it occurs with both gray and spheroidal graphite cast irons [11]. These inconsistent results come from the complexity of graphitic corrosion. To elucidate the mechanisms of corrosion of cast iron, intensive studies are required. In this paper, the electrochemical dissolution of ferrous matrix is discussed.

Cast iron is composed of pearlitic matrix, ferritic matrix, and graphite particles. The area of pearlite influences the physical properties such as tensile strength, elongation, and hardness [12]. Pearlitic matrix is a lamellar mixture of ferrite and cementite. Thus, the length of interfaces between ferrite and cementite becomes large with increasing pearlite area. Fontana [9, pages 28-31] and Trethewey and Chamberlain [13] described in their books that grain boundaries are highenergy areas and are more active chemically. The book by Evans said that regions near the grain boundaries may possess electrochemical properties different from those of the grain interiors [14]. Therefore, the area of pearlite may influence the mechanism and the rate of anodic dissolution of ferrous matrix.

To the authors' knowledge, there are few studies on the dissolution reaction mechanism of cast iron. The objective of the present investigation is to determine the kinetic parameters and the rate equation of anodic dissolution reaction of spheroidal graphite cast iron having different areas of pearlite in sulfuric acid solutions. 
TABLE 1: Chemical composition of the spheroidal graphite cast iron (mass\%).

\begin{tabular}{lcccccc}
\hline $\mathrm{C}$ & $\mathrm{Si}$ & $\mathrm{Mn}$ & $\mathrm{P}$ & $\mathrm{S}$ & $\mathrm{Cu}$ & $\mathrm{Mg}$ \\
\hline 3.67 & 1.99 & 0.41 & 0.013 & 0.01 & 0.19 & 0.046 \\
\hline
\end{tabular}

TABLE 2: Ratios of the pearlite area, the graphite particles area, and the ferrite area.

\begin{tabular}{lccc}
\hline Specimen no. & $P_{r}$ & $G_{r}$ & $F_{r}$ \\
& $(1)$ & $(2)$ & $(3)$ \\
\hline 1 & 0 & 0.21 & 0.79 \\
2 & 0.08 & 0.19 & 0.77 \\
3 & 0.29 & 0.20 & 0.65 \\
4 & 0.57 & 0.18 & 0.54 \\
\hline
\end{tabular}

The ratios of the pearlite area, $P_{r}$, the graphite particles area, $G_{r}$, and the ferrite area, $F_{r}$, are defined by (1), (2), and (3), respectively.

\section{Experimental}

2.1. Specimen. The chemical composition of specimens of spheroidal graphite cast iron (hereinafter referred to as cast iron) is given in Table 1. Cast irons which have different areas of pearlite were prepared. A sand mold, given in Figure 1, was used for casting. Specimens were clipped from the plate which was $5 \mathrm{~mm}$ thick. The ratio of pearlite area to total surface area, $P_{r}$, was controlled by changing heat treatment process, as shown in Figure 2. The cast irons were composed of pearlitic matrix, ferritic matrix, and graphite particles. $P_{r}$ and the ratio of the graphite particles area to total surface area, $G_{r}$, were defined, respectively:

$$
\begin{aligned}
P_{r} & =\frac{\text { Area of pearlitic matrix }}{\text { Total surface area }}, \\
G_{r} & =\frac{\text { Area of graphite particles }}{\text { Total Surface area }} .
\end{aligned}
$$

Pearlitic matrix is a lamellar mixture of ferrite and cementite. If it is assumed that the area of ferrite in pearlitic matrix is as large as that of cementite, the ratio of the ferrite area to total surface area, $F_{r}$, is expressed by

$$
F_{r}=1-G_{r}-\frac{P_{r}}{2} \text {. }
$$

$F_{r}$ decreases from 0.79 to 0.54 with increasing $P_{r}$ from 0 to 0.57 , as shown in Table 2, while $G_{r}$ does not change. The average diameter of graphite particles in all specimens was approximately $20 \mu \mathrm{m}$. Figure 3 shows microscopic photographs of specimens.

The cast iron of $1 \mathrm{~cm}^{2}$ was grinded with a 1000 grit silicon carbide $(\mathrm{SiC})$ paper, degreased with acetone, etched in $1 \mathrm{M}$ $\mathrm{H}_{2} \mathrm{SO}_{4}$ solution for 5 seconds at $323 \mathrm{~K}$, rinsed with distilled water, and dried in air.

2.2. Test Solutions. Sulfuric acid solutions at $\mathrm{pH}=1.0,2.0$, and 3.0 were prepared. Those test solutions contained $\mathrm{Na}_{2} \mathrm{SO}_{4}$ as a supporting electrolyte so as to keep ionic strength at $0.5 \mathrm{~mol} \mathrm{dm}^{-3}$. The test solutions were deaerated with pure

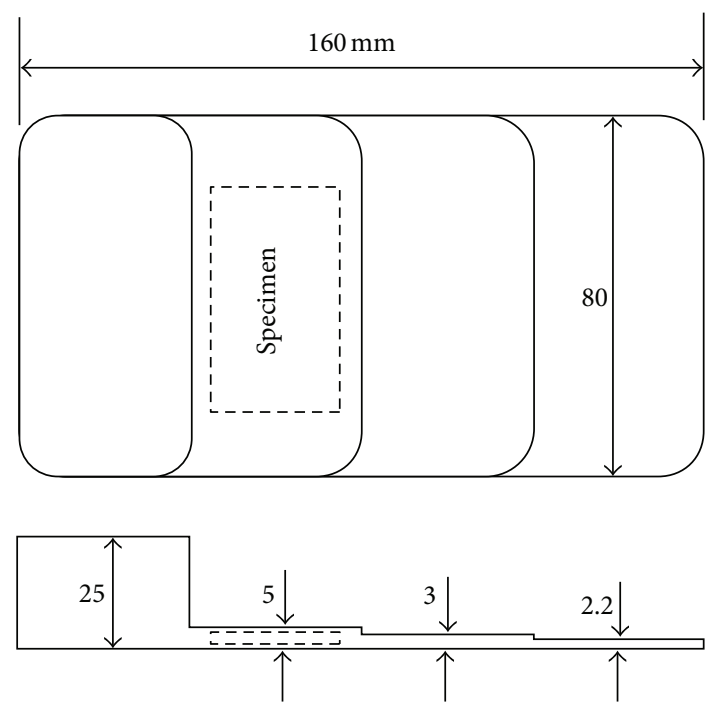

Figure 1: Sand mold and clipping position of specimens.

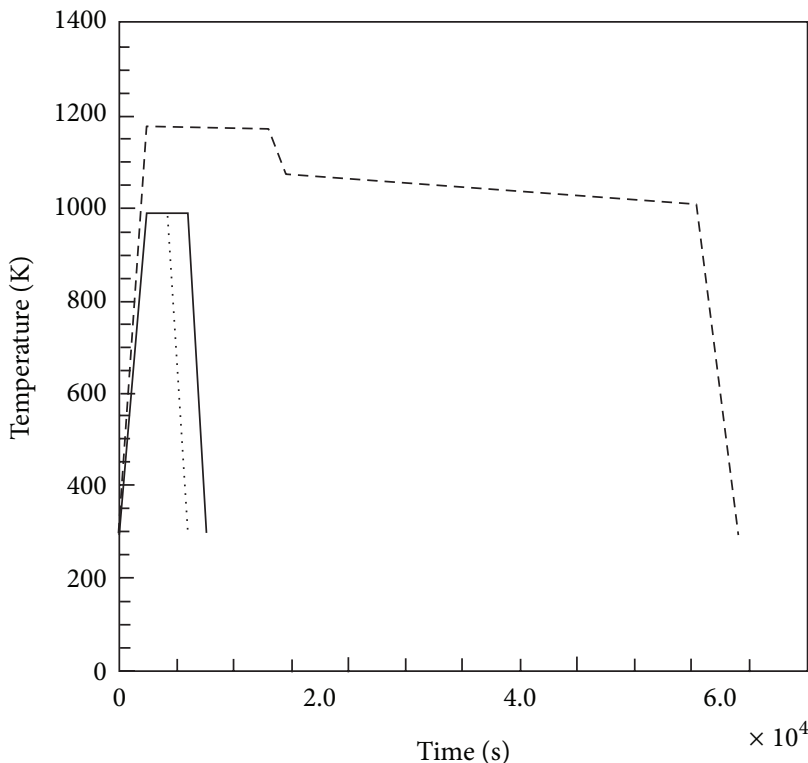

Specimen no. in Table 2

$$
\begin{array}{llll}
--- & 1 & \ldots & 3 \\
- & 2 & \text { As cast } & 4
\end{array}
$$

FIGURE 2: Heat treatment processes of specimens.

nitrogen and agitated with a stirring bar. The rotating speed of the stirring bar did not affect the anodic current densities.

2.3. Measurements. The specimen was set in an empty cell. Pure nitrogen was passed through the cell for 3600 seconds. The specimen was not exposed to the air after it was set in the cell. The test solution deaerated with pure nitrogen in a reservoir was introduced to the cell. The corrosion potential was measured for 600 seconds after the specimen was exposed to the test solution. Subsequently, the linear potential sweep from the corrosion potential started. The 


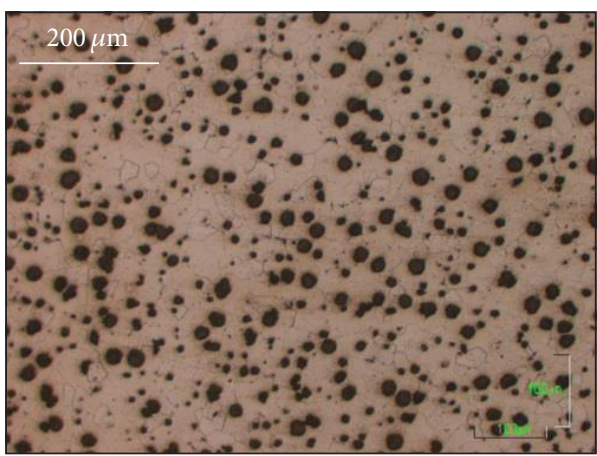

Specimen no. $1\left(P_{r}=0\right)$

(a)

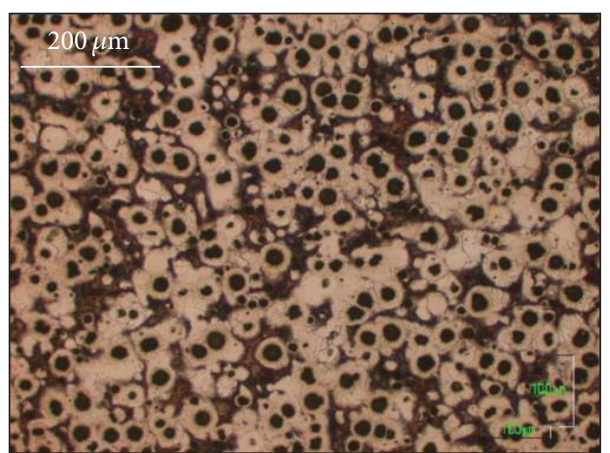

No. $3\left(P_{r}=0.29\right)$

(c)

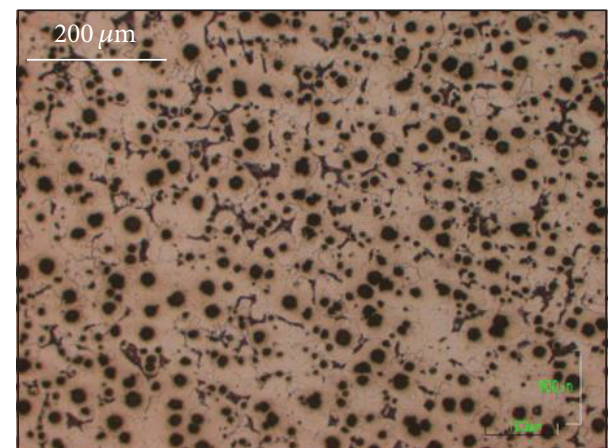

No. $2\left(P_{r}=0.08\right)$

(b)

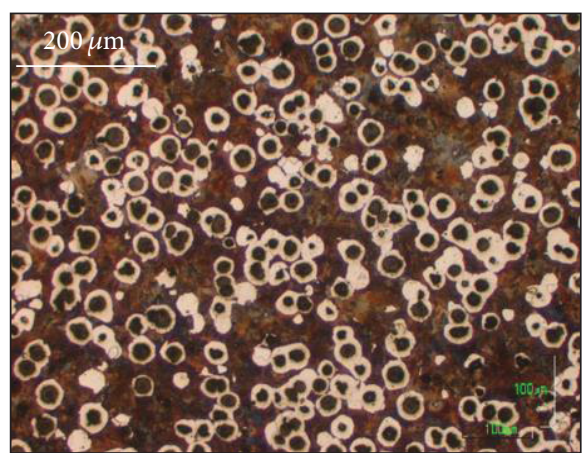

No. $4\left(P_{r}=0.57\right)$

(d)

FIgURE 3: Microscopic photographs of the specimens.

sweep rate was ranged from 0.005 to $0.1 \mathrm{~V} \mathrm{~s}^{-1}$. A new test piece was used for each measurement. The counter electrode was platinum. A $\mathrm{KCl}$ saturated $\mathrm{Ag}$ - $\mathrm{AgCl}$ reference electrode was used. The solution resistance between the specimen and the reference electrode was measured by ac impedance method, with a frequency of $2 \mathrm{kHz}$ and an amplitude of $0.010 \mathrm{~V}$. The electrode potential was expressed on the SHE scale after the correction of the ohmic potential drop. All electrochemical measurements were performed at $298 \mathrm{~K}$. Areas of cementite and graphite particles are assumed not to take part in the anodic dissolution. The anodic current density was calculated from

$$
i_{a}=\frac{I_{a}}{A \cdot F_{r}},
$$

where $i_{a}$ is the anodic current density, $I_{a}$ is the observed anodic current, and $A$ is the total surface area.

\section{Results and Discussion}

3.1. Anodic Current Density due to Dissolution of Cast Iron. The steady-state anodic current can be measured when the sweep rate is lower than $0.1 \mathrm{~V} \mathrm{~s}^{-1}$. Figure 4 shows the anodic polarization curves of the specimen no. 3 in a sulfuric acid solution at $\mathrm{pH}=2.0$. The anodic current densities do not depend on the sweep rates in the range of 0.005 to $0.1 \mathrm{~V} \mathrm{~s}^{-1}$.

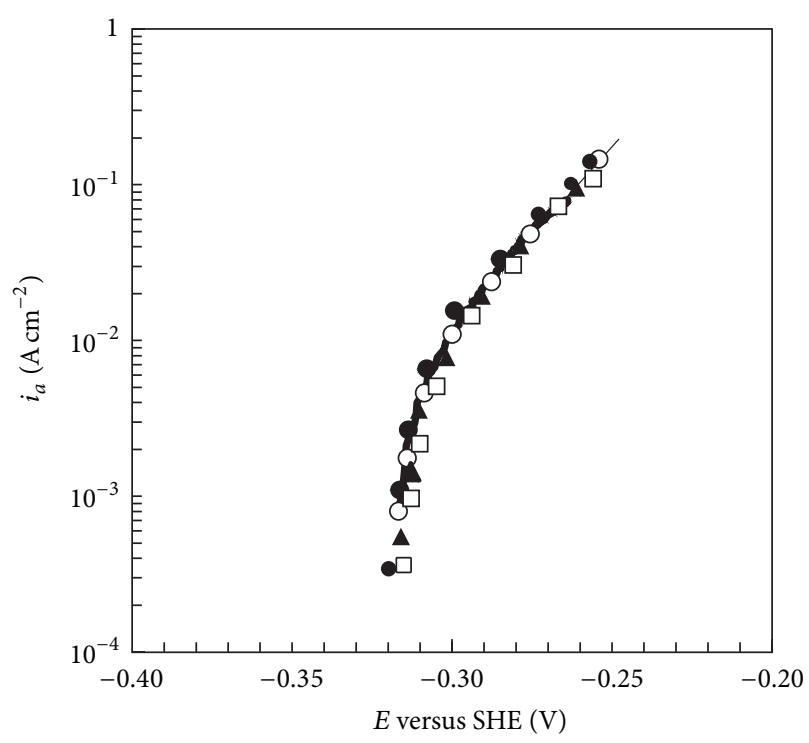

FIgURE 4: Anodic polarization curves of the specimen no. 3 in a sulfuric acid solution at $\mathrm{pH}=2.0$, with a variety of potential sweep rates: (०) $0.1 \mathrm{~V} \mathrm{~s}^{-1},(\mathbf{\Delta}) 0.05 \mathrm{~V} \mathrm{~s}^{-1}$, (口) $0.01 \mathrm{~V} \mathrm{~s}^{-1}$, and $(\bullet) 0.005 \mathrm{~V} \mathrm{~s}^{-1}$.

The sweep rates in this range do not affect the polarization curves at other $\mathrm{pHs}$. 


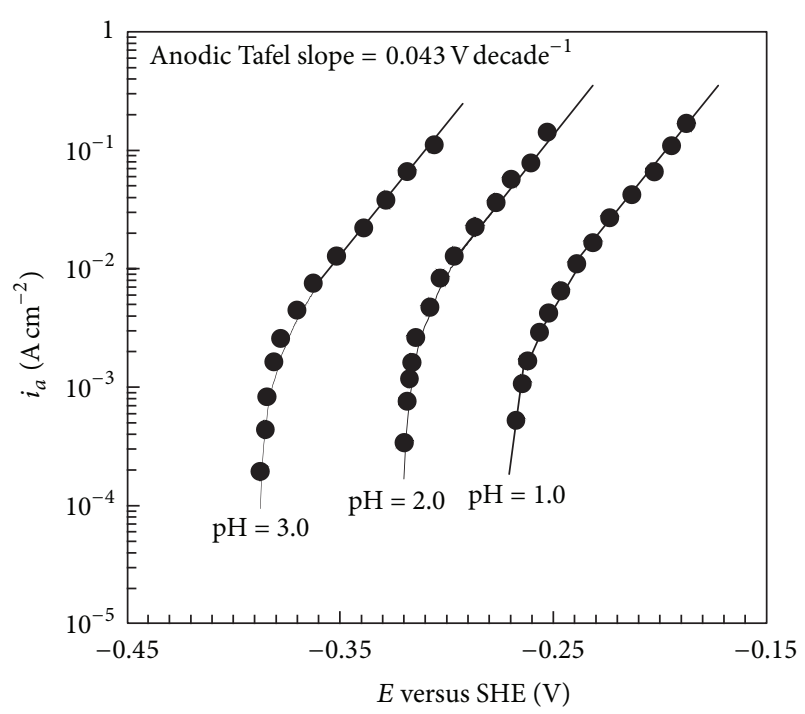

FIgURE 5: Anodic polarization curves of the specimen no. 3 in sulfuric acid solutions at $\mathrm{pH}=1.0,2.0$, and 3.0, with a potential sweep rate of $0.01 \mathrm{~V} \mathrm{~s}^{-1}$.

Figure 5 illustrates the steady-state anodic polarization curves of the specimen no. 3 at pHs 1.0 to 3.0, with a potential sweep rate of $0.01 \mathrm{~V} \mathrm{~s}^{-1}$. Each curve has a Tafel region covering more than one decade. The anodic Tafel slopes are $0.043 \mathrm{~V}$ decade ${ }^{-1}$.

It is clear that the anodic current density due to the dissolution of the cast iron at a constant electrode potential depends on $\mathrm{pH}$, as shown in Figure 5. The anodic current density is expressed by (5) in which the reaction order, $n$, will be discussed in Section 3.3. Consider

$$
i_{a}=k_{a} \cdot\left(a_{\mathrm{OH}^{-}}^{s}\right)^{n} \cdot \exp \left(\frac{2.3 E}{0.043}\right),
$$

where $k_{a}$ is the rate constant of the anodic reaction, $a_{\mathrm{OH}^{-}}^{s}$ is the hydroxyl ion activity at the electrode surface, and $E$ is the electrode potential.

The anodic dissolution reaction is controlled by surface reaction process, because convective conditions do not affect polarization curves. Therefore, the hydroxyl ion activity at the electrode surface is the same as that in the bulk solution. The Tafel slope of $0.043 \mathrm{~V} \mathrm{decade}^{-1}$ in (5) is very close to $(2 / 3)$. $(2.3 R T / F)$. The anodic current density, $i_{a}$, of the cast iron can be expressed by

$$
i_{a}=k_{a} \cdot\left(a_{\mathrm{OH}^{-}}^{*}\right)^{n} \cdot \exp \left(\frac{3 F E}{2 R T}\right),
$$

where $a_{\mathrm{OH}^{-}}^{*}$ is the hydroxyl ion activity in the bulk solution, $F$ is the Faraday constant, $R$ is the gas constant, and $T$ is the absolute temperature.

3.2. Effect of the Ratio of the Pearlite Area on the Anodic Current Density. A relation of the ratio of the pearlite area, $P_{r}$, to the anodic current density, $i_{a}$, is discussed. Figure 6 shows the plots of $\log i_{a}$ against $P_{r}$ at a few constant electrode potentials and pHs. The effect of $P_{r}$ on the anodic current

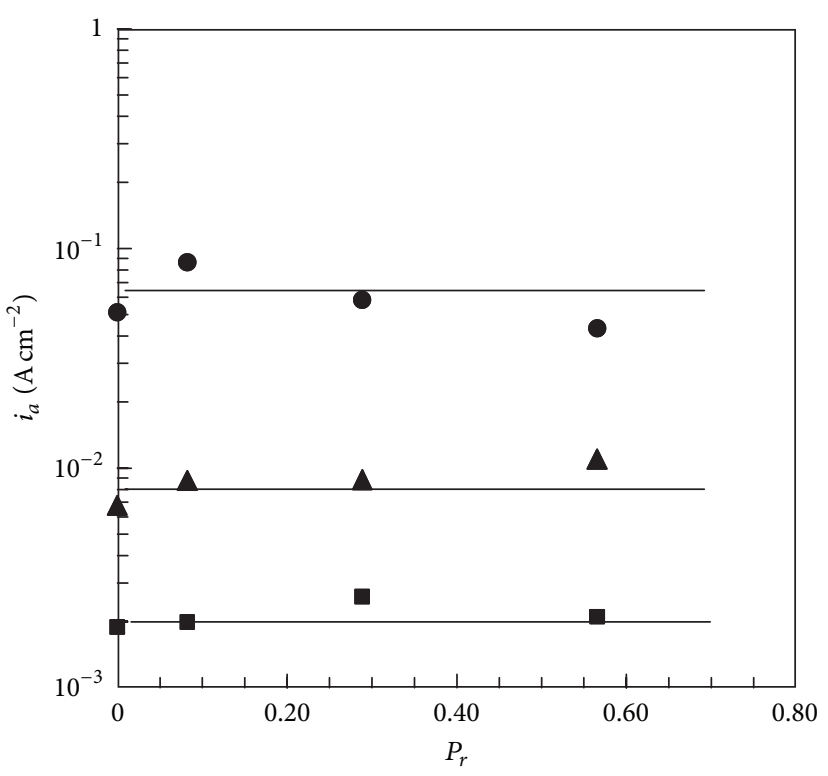

\begin{tabular}{|c|c|c|}
\hline Marks & $E / V$ & $\mathrm{pH}$ \\
\hline $\boldsymbol{\bullet}$ & -0.22 & 1.0 \\
\hline $\boldsymbol{\Delta}$ & -0.30 & 2.0 \\
\hline $\boldsymbol{\square}$ & -0.37 & 3.0 \\
\hline
\end{tabular}

FIgURE 6: Anodic current densities as a function of the ratio of the pearlite area, $P_{r}$, at a few constant electrode potentials and $\mathrm{pHs}$.

density is not observed. This means that the acceleration of anodic dissolution at interfaces between ferrite and cementite can be negligible.

3.3. Determination of the Reaction Order with respect to the Hydroxyl Ion Activity. Three approaches for determining the reaction order with respect to the hydroxyl ion activity are examined.

3.3.1. First Approach. The reaction order, $n$, is given by partially differentiating $\log i_{a}$ with respect to $\mathrm{pH}$ in (6). Consider

$$
n=\left(\frac{\partial \log i_{a}}{\partial \mathrm{pH}}\right)_{E} .
$$

Figure 7 shows the plots of $\log i_{a}$ against $\mathrm{pH}$ for any specimens nos. from 1 to 4 at $E=-0.30 \mathrm{~V}$. As the figure shows, a straight line with a slope of 1 is obtained.

3.3.2. Second Approach. The partial differentiation of $E$ with respect to $\mathrm{pH}$ is expressed by

$$
\left(\frac{\partial E}{\partial \mathrm{pH}}\right)_{i_{a}}=-\left(\frac{2 n}{3}\right)\left(\frac{2.3 R T}{F}\right) .
$$

Equation (8) presents that the electrode potential at a constant anodic current density is a linear function of $\mathrm{pH}$. If $n=1$ in (8), the value of the right side is equal to $-0.040 \mathrm{~V} \mathrm{pH}^{-1}$ at $298 \mathrm{~K}$. The relationships between the electrode potential at 


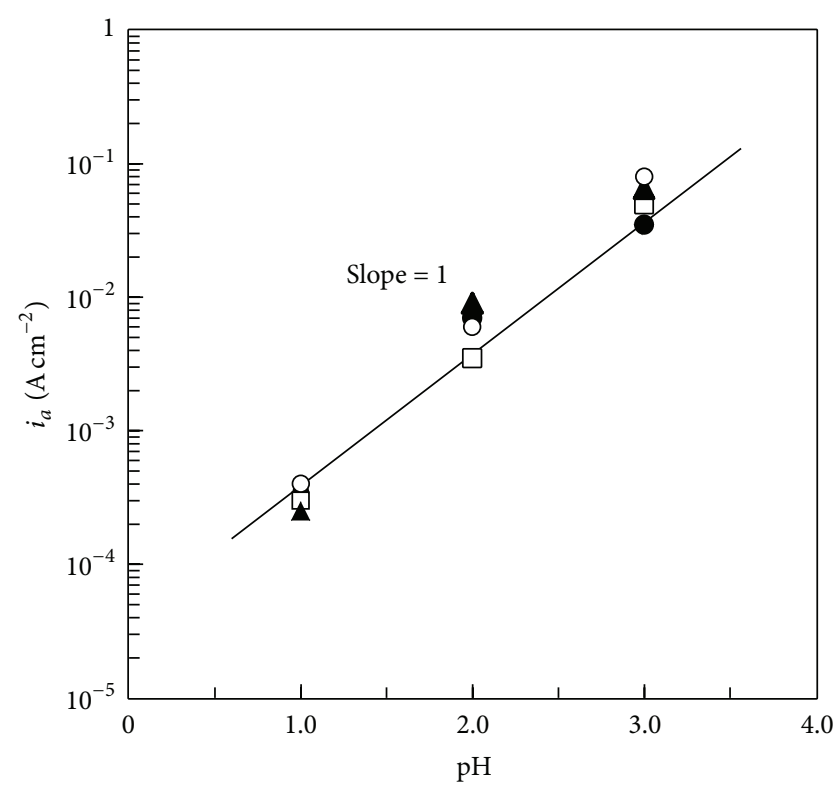

FIGURE 7: Effect of $\mathrm{pH}$ on the anodic current density in sulfuric acid solutions at $E=-0.30 \mathrm{~V}$. The ratio of pearlite area, $P_{r}:(\bullet) 0$, (口) 0.08 , (A) 0.29 , and (o) 0.57 .

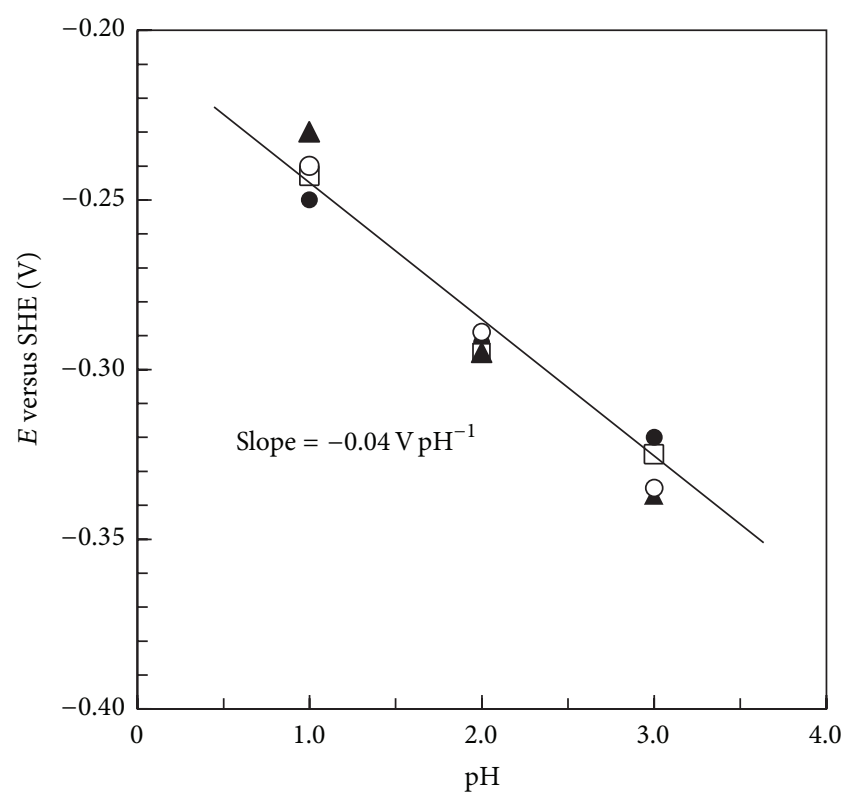

FIGURE 8: Plots of $E$ against $\mathrm{pH}$ in sulfuric acid solutions at $i_{a}=$ $0.01 \mathrm{~A} \mathrm{~cm}^{-2}$. The ratio of pearlite area, $P_{r}:(\bullet) 0$, (口) 0.08 , (ㅅ) 0.29, and (o) 0.57 .

$i_{a}=0.01 \mathrm{~A} \mathrm{~cm}^{-2}$ and $\mathrm{pH}$ for any specimens are shown in Figure 8. The straight line with a slope of $-0.040 \mathrm{~V} \mathrm{pH}^{-1}$ is drawn.

3.3.3. Third Approach. The effect of $\mathrm{pH}$ on the corrosion potential is discussed. The anodic current and the cathodic current are equal at the corrosion potential. Bockris et al. and

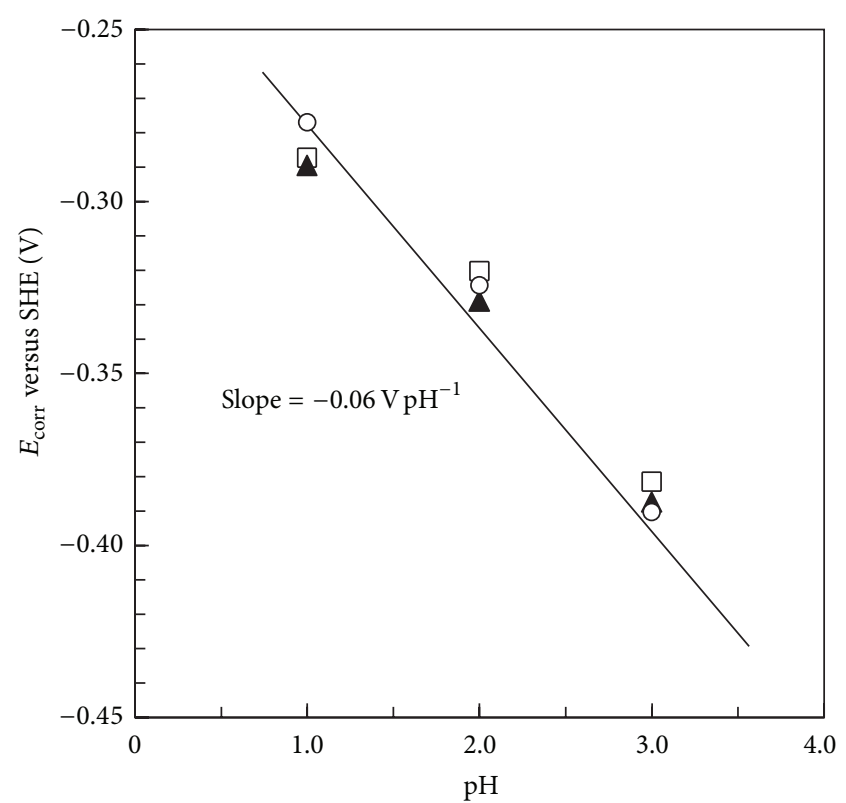

FIGURE 9: Relation between the corrosion potential, $E_{\text {corr }}$, and $\mathrm{pH}$ in sulfuric acid solutions. The ratio of pearlite area, $P_{r}:(\bullet) 0$, (口) 0.08 , (৯) 0.29 , and (o) 0.57 .

Kelly have revealed that the cathodic current density of pure iron is as follows $[15,16]$ :

$$
i_{c}=k_{c} \cdot a_{\mathrm{H}^{+}}^{*} \cdot \exp \left(-\frac{F E}{2 R T}\right)
$$

where $i_{c}$ is the cathodic current density and $k_{c}$ is the rate constant of the cathodic reaction. The present authors have confirmed that the cathodic current density of spheroidal graphite cast iron is also given by (9). The cathodic current is the product of $i_{c}$ and total surface area. The anodic current is calculated by (4) and (6). The corrosion potential is represented in (10), by combining (4), (6), and (9). Consider

$$
E_{\text {corr }}=\frac{2.3 R T}{2 F}\left\{\log \frac{k_{c}}{F_{r} \cdot k_{a} \cdot k_{w}{ }^{n}}-(n+1) \cdot \mathrm{pH}\right\},
$$

where $E_{\text {corr }}$ is the corrosion potential and $k_{w}$ is ionization constant of water. Therefore, the effect of $\mathrm{pH}$ on the corrosion potential is given by

$$
\left(\frac{\partial E_{\mathrm{corr}}}{\partial \mathrm{pH}}\right)=-(n+1)\left(\frac{2.3 R T}{2 F}\right) .
$$

By assuming that $n=1$, the value of the right side in (11) is equal to $-0.060 \mathrm{~V} \mathrm{pH}^{-1}$ at $298 \mathrm{~K}$. Figure 9 shows the plots of $E_{\text {corr }}$ versus $\mathrm{pH}$ for any specimens of nos. 1 to 4 . The linear relation between $E_{\text {corr }}$ and $\mathrm{pH}$ is confirmed, as shown in the figure. The observed slope is precisely $-0.060 \mathrm{~V} \mathrm{pH}^{-1}$.

It is proved that the three approaches reach the same result of $n=1$.

3.4. Mechanism of Anodic Dissolution Reaction of Cast Iron. The mechanisms of iron dissolution reaction in acid solutions 
TABLE 3: Kinetic parameters of typical mechanisms for iron dissolution reaction.

\begin{tabular}{lcc}
\hline Pieces of literature & $b_{a}$ & $n$ \\
\hline Heusler et al. [18-20] & $(1 / 2) \cdot(2.3 R T / F)$ & 2 \\
Bockris et al. [15] & $(2 / 3) \cdot(2.3 R T / F)$ & 1 \\
Abdul Azim and Sanad [37] & $2.3 R T / F$ & 1 \\
\hline
\end{tabular}

Note: $b_{a}$ is the anodic Tafel slope, and $n$ is the reaction order with respect to the hydroxyl ion activity.

have been proposed by many researchers [15-37]. The kinetic parameters of typical mechanisms are summarized in Table 3. In the mechanism by Bonhoeffer and Heusler, the anodic Tafel slope is $0.030 \mathrm{~V}$ decade ${ }^{-1}$ at $298 \mathrm{~K}$, and the reaction order with respect to the hydroxyl ion activity is 2 [18-20]. According to Bockris et al., the anodic dissolution reaction is characterized by the anodic Tafel slope of $0.040 \mathrm{~V}_{\text {decade }}{ }^{-1}$ at $298 \mathrm{~K}$ and the first order dependency on the hydroxyl ion activity [15]. Abdul Azim and Sanad reported that the anodic Tafel slope was $0.060 \mathrm{~V}$ decade $^{-1}$ at $298 \mathrm{~K}$, and the reaction order with respect to the hydroxyl ion activity was 1 [37]. These results refer to different experimental conditions. Lorenz et al. studied the effect of heat treatment of iron on the anodic dissolution rate $[21,38]$. They found that the anodic Tafel slope was $0.030 \mathrm{~V}$ decade ${ }^{-1}$ when the specimen was annealed at a temperature lower than $673 \mathrm{~K}$. The anodic Tafel slope was $0.040 \mathrm{~V} \mathrm{decade}^{-1}$ for the specimen annealed at a temperature higher than $1023 \mathrm{~K}$.

In the present study, the specimens experienced heat treatment at $993 \mathrm{~K}$ and $1173 \mathrm{~K}$ to change the pearlite area. The iron wire electrodes used in the Bockris study were heated in a furnace for 15 minutes at temperatures between 873 and $1173 \mathrm{~K}$ before electrochemical measurements. The Tafel slope of $0.040 \mathrm{~V}$ decade $^{-1}$ obtained by the present authors' and Bockris' experiments substantiates the findings by Lorenz et al. The authors' results support the following mechanism of the anodic dissolution of iron proposed by Bockris et al. [15] . Consider

$$
\begin{gathered}
\mathrm{Fe}+\mathrm{OH}^{-}=(\mathrm{FeOH})_{\mathrm{ads}}+\mathrm{e} \\
(\mathrm{FeOH})_{\mathrm{ads}} \longrightarrow(\mathrm{FeOH})^{+}+\mathrm{e} \quad[\text { rate determining }], \\
(\mathrm{FeOH})^{+}=\mathrm{Fe}^{2+}+\mathrm{OH}^{-}
\end{gathered}
$$

The anodic current density is expressed from the plots in Figures 5 to 8 as follows:

$$
\log i_{a}=\frac{3 F E}{2.3 \cdot 2 R T}+\mathrm{pH}+(3.5 \pm 0.3) .
$$

For pure iron, Kelly has revealed that the rate equation of the anodic dissolution of iron is as follows [16]:

$$
\log i_{a}=\frac{3 F E}{2.3 \cdot 2 R T}+\mathrm{pH}+2.6 .
$$

The anodic current density of the cast iron is higher than that of the pure iron. Alloyed sulfur and phosphorus tend to promote the anodic reaction, even if the content of these elements is lower than $0.02 \%[11,39]$. The cast iron in the present study contains $0.01 \%$ sulfur and $0.013 \%$ phosphorus. The anodic current density of the cast iron is considered to be stimulated by these elements.

\section{Conclusions}

The anodic dissolution of spheroidal graphite cast iron with different pearlite areas in sulfuric acid solutions is studied. The main results are as follows.

(1) The anodic current density of cast iron is expressed by

$$
i_{a}=k_{a} \cdot a_{\mathrm{OH}^{-}}^{*} \cdot \exp \left(\frac{3 F E}{2 R T}\right)
$$

which is consistent with that of pure iron proposed by Bockris et al.

(2) The anodic current density does not depend on the area of pearlite. The acceleration of anodic dissolution at interfaces between ferrite and cementite can be negligible.

(3) No difference in anodic dissolution reaction mechanisms between pure iron and spheroidal graphite cast iron is found.

\section{References}

[1] M. Paris and B. Bruniere, "The corrosion resistance of ductile iron in sea water and petroleum tanker services," Corrosion, vol. 13, no. 5, pp. 292-296, 1957.

[2] F. L. Laque, "The corrosion resistance of ductile iron," Corrosion, vol. 14, no. 10, pp. 485-492, 1958.

[3] B. McEnaney and D. C. Smith, "Corrosion of a cast iron boiler in a model central heating system," Corrosion Science, vol. 18, no. 7, pp. 591-603, 1978.

[4] D. C. Smith and B. McEnaney, "The influence of dissolved oxygen concentration on the corrosion of grey cast iron in water at 50 C," Corrosion Science, vol. 19, no. 6, pp. 379-394, 1979.

[5] B. McEnaney and D. C. Smith, "The reductive dissolution of $\gamma$ FeOOH in corrosion scales formed on cast iron in near-neutral waters," Corrosion Science, vol. 20, no. 7, pp. 873-886, 1980.

[6] L. M. Al-Shama, J. M. Saleh, and N. A. Hikmat, "Potentiostatic studies of the corrosion of grey cast iron in sulphuric acid and sodium hydroxide solutions," Corrosion Science, vol. 27, no. 3, pp. 221-228, 1987.

[7] R. Mehra and A. Soni, "Cast iron deterioration with time in various aqueous salt solutions," Bulletin of Materials Science, vol. 25, no. 1, pp. 53-58, 2002.

[8] A. Reynaud, "Corrosion of cast irons," in Shreir's Corrosion, T. J. A. Richardson, Ed., vol. 3, Chapter 2, pp. 1737-1788, Elsevier, Amsterdam, The Netherlands, 2010.

[9] M. G. Fontana, Corrosion Engineering, McGraw-Hill, New York, NY, USA, 1987.

[10] K. Horikawa, S. Takiguchi, Y. Ishizu, and M. Kanazashi, "Studies on the atmospheric corrosion of metals and anti-corrosive coatings in Japan (5th Report)," Boushoku-Gijutsu[Corrosion Engineering of Japan], vol. 16, no. 4, pp. 153-158, 1967.

[11] H. H. Uhlig, Corrosion and Corrosion Control, John Wiley \& Sons, New York, NY, USA, 1963. 
[12] K. Nakamura and H. Sumimoto, "Relationship between microstructure and stress-strain curve of grey cast iron," Imono, vol. 39, no. 6, pp. 480-493, 1967.

[13] K. R. Trethewey and J. Chamberlain, Corrosion for Science and Engineering, Longman; GBR, Essex, UK, 1995.

[14] U. R. Evans, The Corrosion and Oxidation of Metals: Scientific Principles and Practical Applications, Edward Arnold; GBR, London, UK, 1960.

[15] J. O’M. Bockris, D. Drazic, and A. R. Despic, "The electrode kinetics of the deposition and dissolution of iron," Electrochimica Acta, vol. 4, no. 2-4, pp. 325-361, 1961.

[16] E. J. Kelly, "The active iron electrode I. Iron dissolution and hydrogen evolution reactions in acidic sulfate solutions," Journal of the Electrochemical Society, vol. 112, no. 2, pp. 124-131, 1965.

[17] A. J. Bard, Encyclopedia of Electrochemistry of the Elements, Marcel Dekker, New York, NY, USA, 1982.

[18] K. F. Bonhoeffer and K. E. Heusler, "Abhängigkeit der anodischen Eisenauflösung von der Säurekonzentration," Zeitschrift Für Physikalische Chemie, vol. 8, pp. 390-393, 1956.

[19] K. F. Bonhoeffer and K. E. Heusler, "Bemerkung über die anodische Auflösung von Eisen," Zeitschrift Für Elektrochemie, Berichte der Bunsengesellschaft Für Physikalische Chemie, vol. 61, no. 1, pp. 122-123, 1957.

[20] K. E. Heusler, "Der Einfluß der Wasserstoffionenkonzentration auf das electrochemische Verhaiten des aktiven Eisens in sauren Lösungen," Zeitschrift Für Elektrochemie, Berichte der Bunsengesellschaft Für Physikalische Chemie, vol. 62, no. 5, pp. 582-587, 1958.

[21] G. Eichkorn, W. J. Lorenz, L. Albert, and H. Fischer, "Einfluß der oberflächenaktivität auf die anodischen auflösungsmechanismen von eisen in sauren lösungen," Electrochimica Acta, vol. 13, no. 2, pp. 183-197, 1968.

[22] T. Hurlen, "Electrochemical behaviour of iron," Acta Chemica Scandinavica, vol. 14, pp. 1533-1554, 1960.

[23] K. E. Heusler and G. H. Cartledge, "The influence of iodide ions and carbon monoxide on the anodic dissolution of active iron," Journal of the Electrochemical Society, vol. 108, no. 8, pp. 732740, 1961.

[24] W. J. Lorenz, H. Yamaoka, and H. Fischer, "Zum electrochemischen Verhalten des Eisens in salzsauren Lösungen," Berichte der Bunsengesellschaft Für Physikalische Chemie, vol. 67, no. 9-10, pp. 932-943, 1963.

[25] W. J. Lorenz, G. Eichkorn, and C. Mayer, "Über den Einfluß von sulfationen auf die kinetik der anodischen Eisenauflösung in sauren lösungen," Corrosion Science, vol. 7, no. 6, pp. 357-365, 1967.

[26] R. M. Shemenski, F. H. Beck, and M. G. Fontana, "Dissolution kinetics and polarization of iron whiskers," Corrosion, vol. 21, no. 2, pp. 39-47, 1965.

[27] C. Voigt, "Beitrag zur kinetik der korrosion von Fe in sauren sulfat- und perchloratlösungen," Electrochimica Acta, vol. 13, no. 10, pp. 2037-2050, 1968.

[28] J. O’M. Bockris and H. Kita, "Analysis of galvanostatic transients and application to the iron electrode reaction," Journal of the Electrochemical Society, vol. 108, no. 8, pp. 676-685, 1961.

[29] J. O'M. Bockris and D. Drazic, "The kinetics of deposition and dissolution of iron: effect of alloying impurities," Electrochimica Acta, vol. 7, no. 3, pp. 293-313, 1962.

[30] T. P. Hoar and R. D. Holliday, "The inhibition by quinolines and thioureas of the acid dissolution of mild steel," Journal of Applied Chemistry, vol. 3, no. 11, pp. 502-513, 1953.
[31] A. C. Makrides, N. M. Komodromos, and N. Hackerman, "Dissolution of metals in aqueous acid solutions," Journal of the Electrochemical Society, vol. 102, pp. 363-369, 1955.

[32] A. C. Makrides, "Dissolution of iron in sulfuric acid and ferric sulfate solutions," Journal of the Electrochemical Society, vol. 107, no. 11, pp. 869-877, 1960.

[33] M. Stern and R. M. Roth, "Anodic behavior of iron in acid solutions," Journal of the Electrochemical Society, vol. 104, no. 6, pp. 390-392, 1957.

[34] L. Felloni, "The effect of $\mathrm{pH}$ on the electrochemicalbehaviour of iron in hydrochloric acid," Corrosion Science, vol. 8, no. 3, pp. 133-148, 1968.

[35] G. J. Bignold and M. Fleischmann, "Identification of transient phenomena during the anodic polarisation of iron in dilute sulphuric acid," Electrochimica Acta, vol. 19, no. 7, pp. 363-374, 1974.

[36] G. Okamota, M. Nagayama, and N. Sato, "Application of the rapid method for the measurement of polarization characteristics of iron in acid solutions," in Proceedings of the 8th Meeting of the International Committee of Electrochemical Thermodynamics and Kinetics (C. I. T. C. E.), pp. 72-89, 1956.

[37] A. A. Abdul Azim and S. H. Sanad, "The anodic dissolution of Fe and C-steel in acidic sulphate solution," Electrochimica Acta, vol. 17, no. 9, pp. 1699-1704, 1972.

[38] W. J. Lorenz and G. Eichkorn, "Einfluß des Subgefüges auf den Mechanismus der anodischen Eisenauflösung in sauren Lösungen," Berichte der Bunsengesellschaft für Physikalische Chemie, vol. 70, no. 1, pp. 99-106, 1966.

[39] M. Stern, "The effect of alloying elements in iron on hydrogen over-voltage and corrosion rate in acid environments," Journal of the Electrochemical Society, vol. 102, no. 12, pp. 663-668, 1955. 

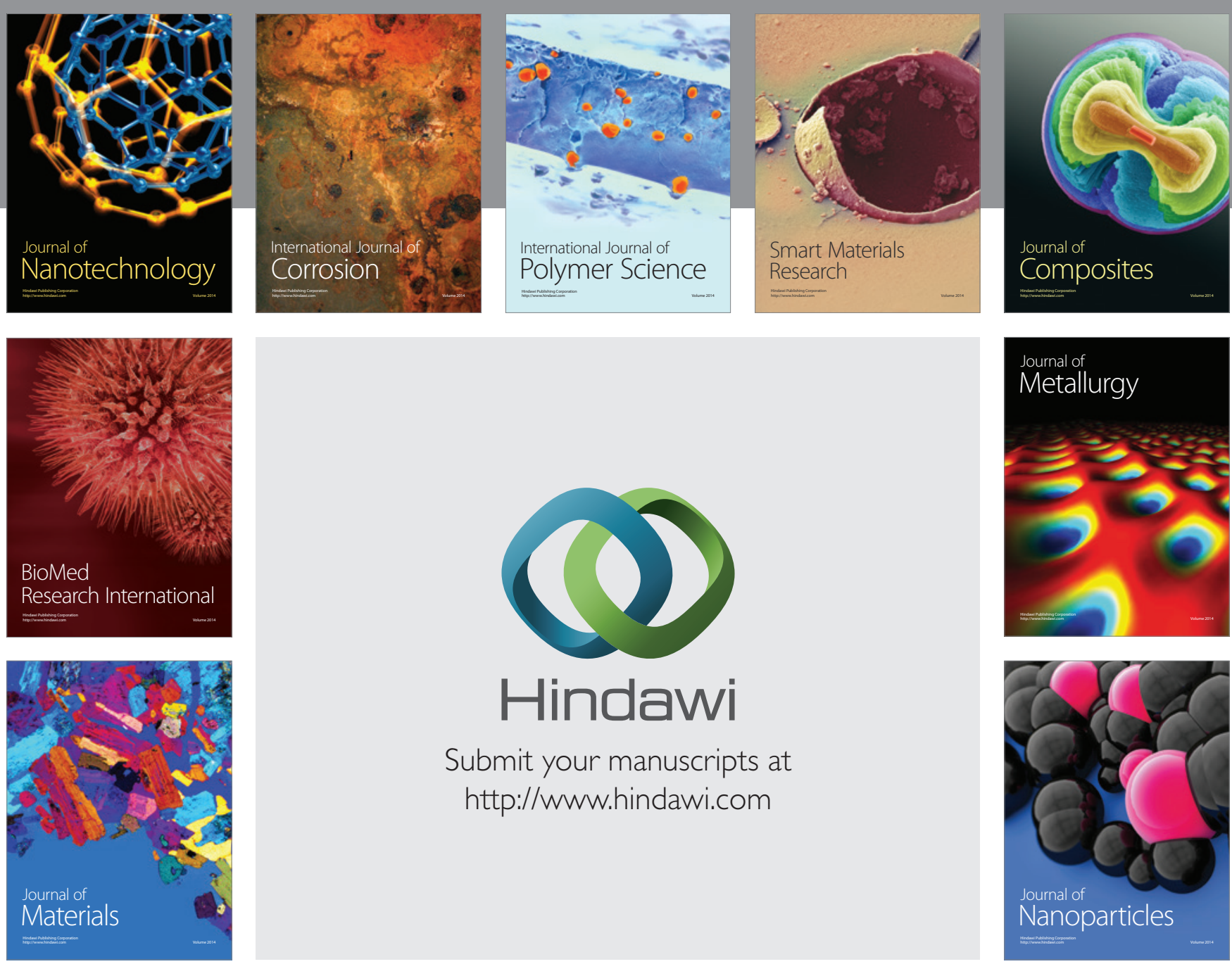

Submit your manuscripts at http://www.hindawi.com
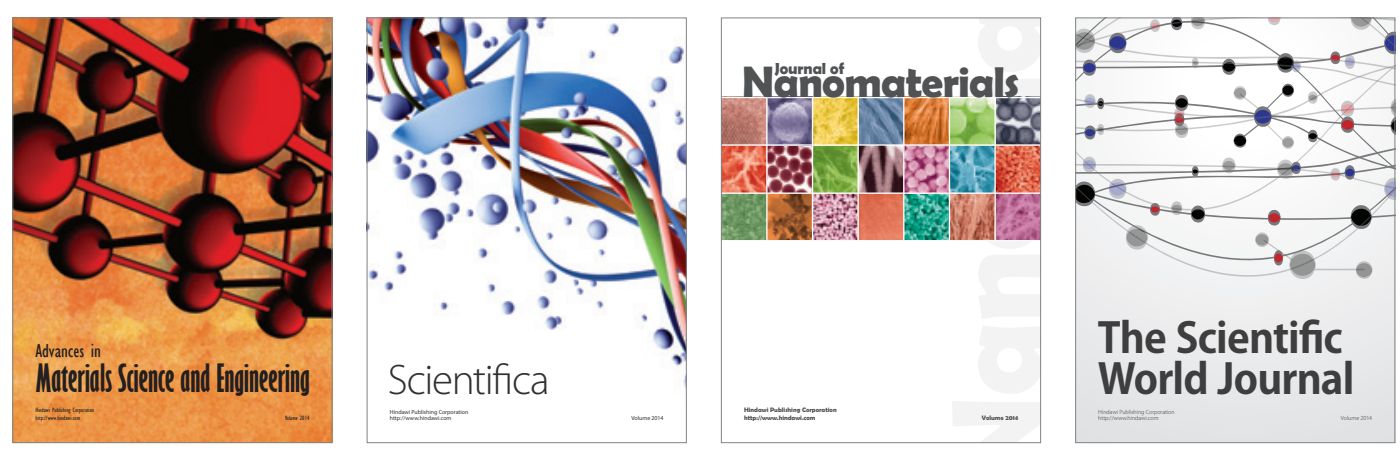

\section{The Scientific World Journal}
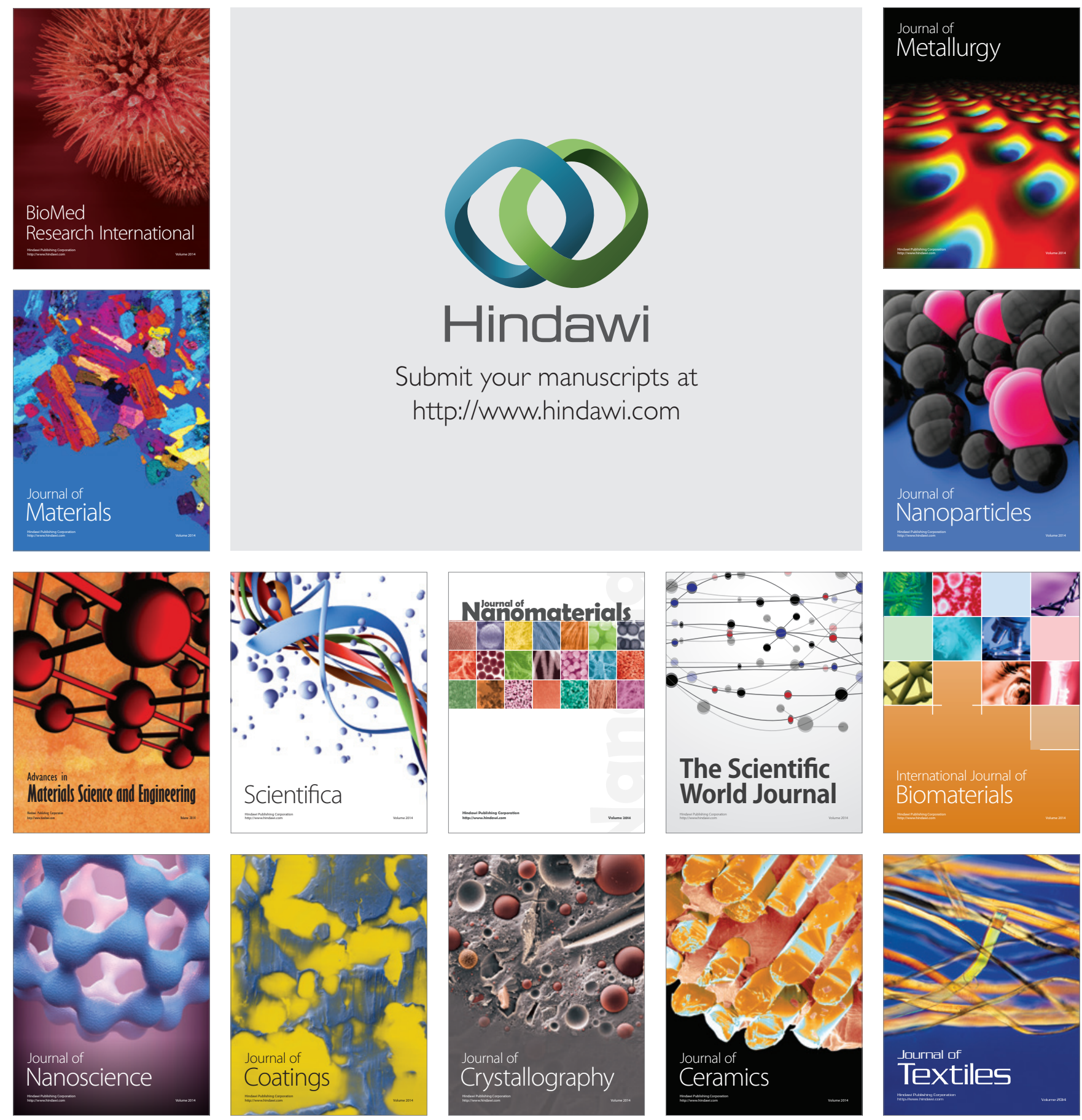